\title{
Inhibition of SIRT1 Sensitizes TRAlL-Resistant MCF-7 Cells by Upregulation of DR5 and Inhibition of c-FLIP
}

\author{
Su-Hoon Lee', Hak-Bong Kim', Mi-Ju Kim', Jae-Won Lee', Jae-Ho Bae', Dong-Wan Kim², \\ Chi-Dug Kang ${ }^{1}$ and Sun-Hee Kim ${ }^{1}$. \\ ${ }^{1}$ Department of Biochemistry and Medical Research Institute, Pusan National University School of Medicine, Yangsan 626-870, Korea \\ ${ }^{2}$ Department of Microbiology, College of Natural Sciences, Changwon National University, Changwon 641-773, Korea
}

Received May 29, 2012 /Revised August 30, 2012 /Accepted September 5, 2012

\begin{abstract}
The tumor necrosis, factor-related, apoptosis-inducing ligand (TRAIL) is regarded as a potentially useful anticancer agent with excellent selectivity for cancer cells. However, a considerable number of cancer cells are resistant to apoptosis induction by TRAIL. Developing strategies to overcome this resistance are important for the successful use of TRAIL for cancer therapy. Here, we revealed that siRNA-mediated downregulation of SIRT1 or SIRT1 inhibitor Amurensin G upregulated DR5 and c-Myc and downregulated c-FLIP $\mathrm{L} / \mathrm{S}$ and Mcl-1, which was associated with sensitization of TRAIL-resistant MCF-7 cells to TRAIL. This result was followed by the activation of caspases, PARP cleavage, and downregulation of Bcl-2 in both TRAIL-treated MCF-7 cells transfected with SIRT1 siRNA and cells co-treated with Amurensin G and TRAIL. Our results suggest that the induction of DR5 and downregulation of c-FLIP via suppression of SIRT1 expression may be a useful strategy to increase the susceptibility of TRAIL-resistant cancer cells to TRAIL-induced cell death.
\end{abstract}

Key words : Tumor necrosis factor-related apoptosis-inducing ligand (TRAIL), SIRT1, c-FLIP, MCF-7 cells, DR5

\section{Introduction}

Tumor necrosis factor - related apoptosis-inducing ligand (TRAIL) has shown remarkable promise as an anticancer agent [31]. TRAIL is a relatively safe and most promising death ligand for clinical application compared with other death ligands of the TNF- $a$ family. It has been shown to exhibit potent tumoricidal activity against a variety of human cancer cell lines in vitro and in vivo with minimal or no toxicity to nonmalignant human cells [2]. TRAIL induces apoptosis in tumor cells by binding to death receptors TRAIL-R1/DR4 and TRAIL-R2/DR5 [26]. These receptors include an intracellular death domain, which triggers the activation of the caspase signaling cascade after association of ligand with the receptor, with or without the involvement of mitochondria [30]. The majority of breast, prostate, ovarian, lung carcinoma, multiple myeloma, and leukemia cells are resistant to apoptosis induced by TRAIL [25]. Resistance of tumor cells to TRAIL seems to occur through the modulation of various molecular targets. These may include differential expression of death receptors, such as low expression

*Corresponding author

Tel : +82-51-510-8081, Fax : +82-51-510-8086

E-mail : ksh7738@pusan.ac.kr of DR4 andDR5, increased surface levels of decoy receptors, overexpression of antiapoptotic molecules, mutations in apoptotic genes, such as Bax and Bak, defects in caspase signaling in resistant cells [25,35]. Several chemotherapeutic drugs in combination with TRAIL result in reversal of resistance to TRAIL-mediated apoptosis through up-regulation of DR5 expression.

It has been reported that inhibition of histone deacetylases (HDACs) that reverses aberrant epigenetic changes have emerged as a potential strategy to sensitize cancer cells for TRAIL-induced apoptosis [8]. HDAC inhibitors as single agents have been shown to cause inhibition of proliferation, differentiation, cell death and suppression of tumor growth in a number of different cancers both in vitro as well as in vivo [5]. In addition to this single agent activity, HDAC inhibitors have been tested in combination with a large variety of different anticancer agents, including classical chemotherapeutic drugs, radiotherapy or proteasome inhibitors $[4,6,12]$. Moreover, HDAC inhibitors can prime tumor cells towards TRAIL-induced apoptosis as demonstrated in a set of different human malignancies [8]. Multiple mechanisms have been put forward to provide an explanation for the HDAC inhibitor-mediated sensitization of cancer cells towards TRAIL receptor-mediated apoptosis [3]. 
HDAC inhibitors can also prime cancer cells for TRAIL-triggered apoptosis by downregulation of antiapoptotic proteins, for example, c-FLIP. Indeed, a variety of class I and II HDAC inhibitors, for example valproic acid, depsipeptide, sodium butyrate, trichostatin A and LAQ824, have been shown to decrease expression levels of c-FLIP $[1,10,20,24,33]$. However, inhibitor of SIRT1 deacetylase, a member of the class III HDAC family, has not been reported to augment TRAIL-induced apoptosis and its mechanism. Here, we determined whether suppression of SIRT1 or amurensin G, a newly identified SIRT1 inhibitor, would sensitize the TRAIL-resistant MCF-7 cells to TRAIL-induced apoptosis.

\section{Materials and Methods}

\section{Cell culture and reagents}

Human breast adenocarcinoma MCF-7 cells were cultured in DMEM medium containing $10 \%(\mathrm{v} / \mathrm{v})$ fetal bovine serum (FBS, Gibco BRL, Life Technologies Inc., USA), penicillin (100 $\mathrm{U} / \mathrm{ml})$, and streptomycin $(100 \mathrm{mg} / \mathrm{ml})$. The cells were maintained in $5 \% \mathrm{CO}_{2} / 95 \% \mathrm{O}_{2}$ at $37^{\circ} \mathrm{C}$. Recombinant human soluble TRAIL was obtained from R\&D Systems (Minneapolis, MN, USA), and amurensin G isolated from the stem of Vitis amurensis [17] was provided by prof. Oh W. K. (Chosun University, Korea).

\section{Apoptosis assay}

MCF-7 Cells $\left(2 \times 10^{5}\right.$ cells $\left./ \mathrm{ml}\right)$ were treated with or without TRAIL and/or amurensin G for the indicated doses. Also, to determine whether TRAIL-induced apoptosis occurs through the death receptors, cells were pretreated with the TRAIL-R1 (anti-DR4) or TRAIL-R2 (anti-DR5) antibody (0.5 $\mathrm{\mu g} / \mathrm{ml}$, R \& D Systems, Minneapolis, MN, USA) or normal goat IgG (Sigma-Aldrich Corp., St Louis, MO, USA) for 2 $\mathrm{h}$ before treatment with TRAIL for $24 \mathrm{~h}$. Apoptosis was the measured by annexin $\mathrm{V}$ assay. The cells were centrifuged and resuspended in $500 \mu \mathrm{l}$ of a staining solution containing annexin V fluorescein (FITC Apoptosis Detection Kit; BD Pharmingen, San Diego, CA, USA) and propidium iodide in PBS. After incubation at room temperature for $15 \mathrm{~min}$, the cells were analyzed by flow cytometry for discrimination of live cells (unstained with either fluorochrome) from apoptotic cells (stained only with Annexin V) and necrotic cells (stained with Annexin $\mathrm{V}$ and propidium iodide).

\section{MTT cell proliferation assay}

Cell proliferation was measured by counting viable cells by using the 3-(4,5-dimethylthiazol-2-yl)-2,5-diphenyltetrazolium bromide (MTT; Sigma Chemical Company, St. Louis, MO, USA) colorimetric dye-reduction method. Exponentially growing MCF-7 cells $\left(2 \times 10^{4}\right.$ cells/well) were plated in a 96-well plate and incubated in growth medium treated with the indicated concentration of TRAIL and/or amurensin $\mathrm{G}$ at $37^{\circ} \mathrm{C}$. After $96 \mathrm{~h}$, the medium was aspirated using centrifugation and MTT-formazan crystals solubilized in $100 \mu \mathrm{l} \mathrm{DMSO}$. The optical density of each sample at 570 $\mathrm{nm}$ was measured using ELISA reader. The optical density of the medium was proportional to the number of viable cells. Inhibition of proliferation was evaluated as a percentage of control growth (no drug in the medium). All experiments were repeated in at least two experiments in triplicate.

\section{Flow cytometric analysis of TRAll receptors}

MCF-7 cells $\left(5 \times 10^{5}\right.$ cells/well) treated with or without TRAIL (or amurensin G) were centrifuged at $500 \times \mathrm{g}$ and resuspended in $500 \mu \mathrm{PBS}$. Cells were then incubated with $5 \mu \mathrm{l}$ of mouse IgG, anti-DR4, or anti-DR5 monoclonal mouse antibody (1:100; R\&D Systems, Minneapolis, MN, USA) for $2 \mathrm{~h}$. After washing with PBS, FITC-conjugated rabbit anti-mouse IgG (1:200; Sigma Chemical Co., St. Louis, MO, USA) was added to cell suspensions, incubated for $2 \mathrm{~h}$ on ice, and washed with PBS. After rinsing, samples were analyzed by flow cytometry using a FACSCalibur flow cytometer (Becton Dickinson, San Jose, CA, USA). The data were analyzed using CellQuest software.

\section{Western blot analysis}

Protein samples were separated by SDS-PAGE and blotted onto nitrocellulose membranes (Hybond-ECL, GE Healthcare Life science, Piscataway, NJ, USA), which were then incubated with specific antibodies followed by secondary antibody conjugated with horseradish peroxidase. Specific antigen-antibody complexes were detected by enhanced chemiluminescence (PerkinElmer, Waltham, MA, USA). Western blot analysis was performed using the following antibodies: SIRT1, caspase-8, caspase-7 (Cell Signaling Technology, Danvers, MA, USA), c-Myc, Mcl-1, Bak and caspase-7 (Epitomics, Burlingame, CA, USA), p21, TERT, PARP, Bcl-2 and Bax (Santa Cruz Biotechnology, Santa Curz, CA, USA), DR5/DR4 (Calbiochem, San Diego,

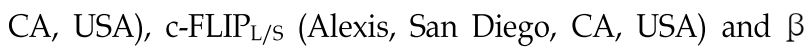


-actin antibody (Sigma-Aldrich Co., St. Louis, MO, USA). Secondary antibodies were obtained from Cell Signaling Technology.

\section{siRNA transfection}

The siRNA used for the targeted silencing of SIRT1 (5'-AACUUCACCACCAGAUUAUUCdTdT-3') and scrambled (5'-CUUCCCGAAAACUUGAGACdTdT-3') were purchased from Bioneer (Daejeon, Korea). In brief, MCF-7 cells $\left(2 \times 10^{5}\right.$ cells $\left./ \mathrm{ml}\right)$ were seeded on 6-well plates and transfected with $0.2 \mu \mathrm{M}$ of siRNA using oligofectamine reagent, according to the manufacturer's instructions (Invitrogen, Carlsbad, CA, USA). Cells were then incubated at $37^{\circ} \mathrm{C}$ for $4 \mathrm{~h}$ in serum free media and FBS was added to $10 \%$. After $48 \mathrm{~h}$, cells were treated with TRAIL for an additional $24 \mathrm{~h}$ and then collected for western blot analysis to determine the levels of SIRT1 and other indicated proteins.

\section{Statistical analysis}

All results were expressed as the mean \pm standard error (SE) of at least three independent experiments performed in triplicate. The statistical significance of difference was assessed using the Student's t-test.

\section{Results}

Suppression of SIRT1 in TRAlL-resistant MCF-7 cells enhanced susceptibility to TRAIL

Since SIRT inhibitors can be used in combinatorial treatments with conventional anticancer therapeutics to enhance the drug efficacy and for overcoming resistance [18], we first determined whether knockdown of SIRT1 could sensitize TRAIL-resistant cells to TRAIL-induced apoptosis using human breast adenocarcinoma MCF-7 cell line, which is well known to be resistant to TRAIL-induced cell death [14]. To validate apoptotic cooperation between TRAIL and knockdown of SIRT1, MCF-7 cells were exposed to TRAIL after transfecting the cells with either SIRT1 siRNA or control scrambled siRNA, and apoptosis was determined $24 \mathrm{~h}$ later using flow cytometric analysis. TRAIL-mediated apoptosis in MCF-7 cells was found to be greatly enhanced by transfection of SIRT1 siRNA compared with transfection of scramble siRNA (Fig. 1). These results suggest that inhibition of SIRT1 potentiates apoptotic activity of TRAIL in MCF-7cells.

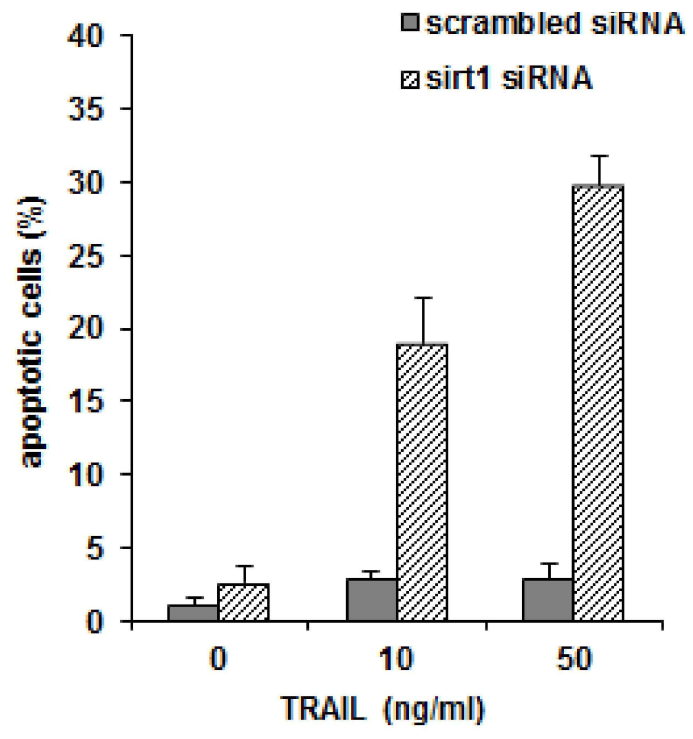

Fig. 1. Enhancement of TRAIL-induced apoptosis by inhibition of SIRT1. MCF-7 cells were transfected with SIRT1 siRNA or scrambled siRNA and after $48 \mathrm{~h}$ treated with various concentrations of TRAIL (10- and $50 \mathrm{ng} / \mathrm{ml}$ ) for $96 \mathrm{~h}$. Cell survival was determined using MTT assay. Percentage of apoptotic cells in each cell population was determined with flow cytometry using Annexin V staining. Each value represents the mean \pm SE of triplicate experiments.

Suppression of SIRT1 up-regulated DR5 cell
surface expression and it was associated with
up-regulation of c-Myc

Next, we determined whether down-regulation of SIRT1 could modulate the cell surface expression of TRAIL receptors since the cell surface expression of DR4/DR5 plays an important role in TRAIL-induced apoptosis [13]. Transfection of MCF-7 cells with SIRT1 siRNA resulted in the differential regulation of the cell surface expression of DR4 and DR5. Cell surface expression of DR5, but not DR4, was markedly increased by transfection of SIRT1 siRNA (Fig. 2).

Since c-Myc can up-regulate the expression of the TRAIL receptor DR5 at the cell surface [32], we examined whether amurensin G, a new natural SIRT1 inhibitor could modulate the expression of c-Myc. When MCF-7 cells were treated with various concentration of amurensin G, SIRT1 expression was profoundly decreased and conversely increased the expressions of DR5 and c-Myc. The expression of TERT (telomerase reverse transcriptase) and Bak were up-regulated but the expression of p21, Mcl-1 and c-FLIP $\mathrm{L}_{\mathrm{L} / \mathrm{s}}$ were down-regulated by amurensin G-induced c-Myc expression (Fig. 3). These results suggest the possibility that 
A
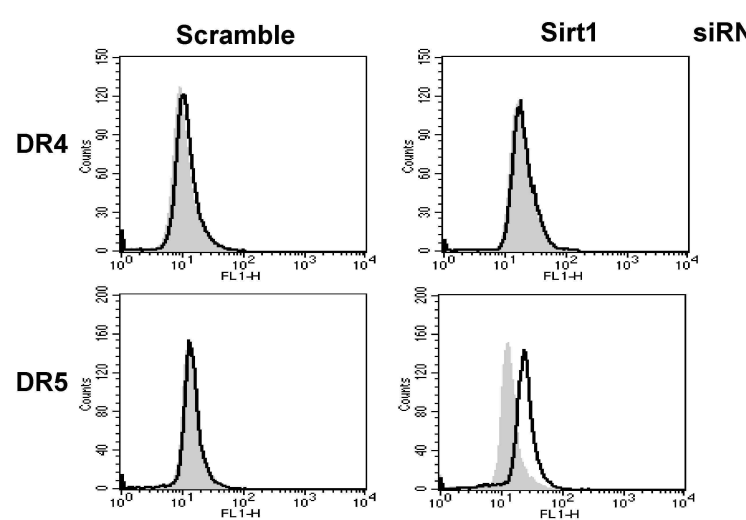

B

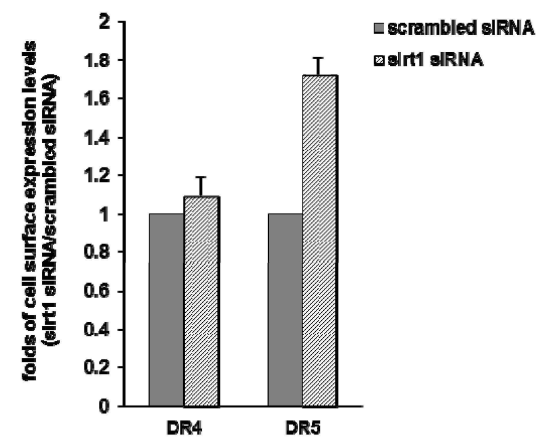

Fig. 2. Enhancement of the cell-surface expression of DR5 by inhibition of SIRT1. A, MCF-7 cells were transfected with SIRT1 siRNA or scrambled siRNA. After $48 \mathrm{~h}$ cells were labeled with control IgG, anti-DR4 or DR5 antibody (1:100) and subsequently stained with FITC-conjugated secondary antibodies (1:200). Cell surface expressions of DR4 and DR5 were quantified by flow cytometry. Shaded and unshaded peaks corresponded to control and specific stainings, respectively. $\mathrm{B}$, the results of cell-surface expression of DR4/DR5 after SIRT1 siRNA transfection, shown in panel A, were quantified and normalized to scrambled siRNA-transfected control cells

the up-regulation of DR5 and down-regulation of c-FLIP after suppression of SIRT1 might be due to the up-regulation of c-Myc. To further confirm the up-regulation of DR5 by amurensin $\mathrm{G}$ treatment, we determined whether treatment of MCF-7 cells with amurensin G modulated the cell surface expression of TRAIL receptors. Our data showed that treatment of MCF-7 cells with amurensin G resulted in the differential regulation of the cell surface expression of DR4 and DR5. Surface expression of DR5, but not DR4, was markedly increased by amurensin $\mathrm{G}$ treatment as determined by FACS analysis (Fig. 4), suggesting that inhibition of SIRT1 resulted in enhanced susceptibility to TRAIL at least in part via the up-regulation of DR5.

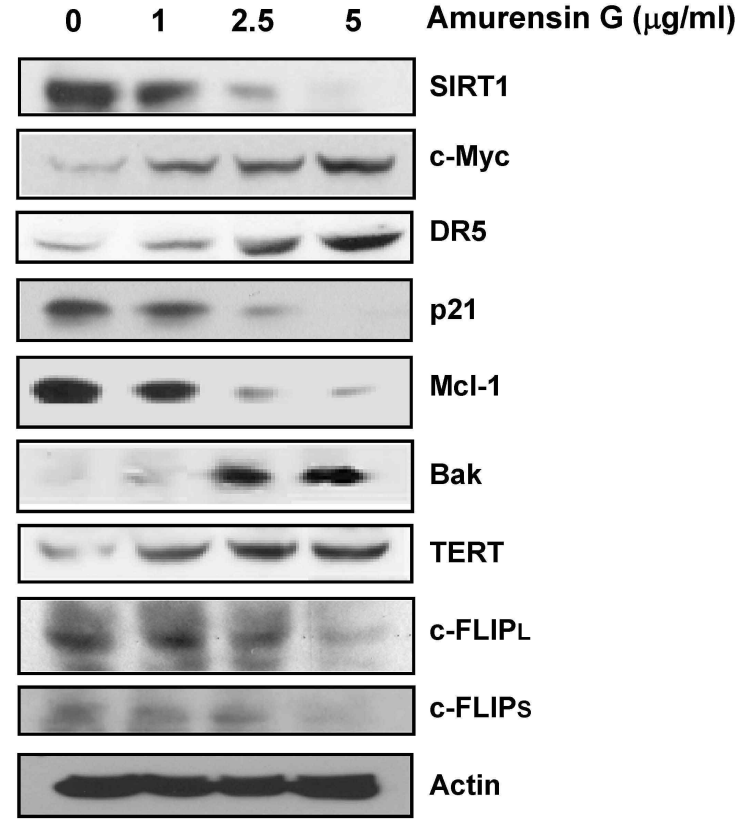

Fig. 3. Up-regulation of c-Myc, TERT, Bak and DR5, and down-regulation of c-FLIP, Mcl-1 and p21 by inhibition of SIRT1. MCF-7 cells were treated with amurensin G $(1-, 2.5-$ and $5 \mu \mathrm{g} / \mathrm{ml})$ for $24 \mathrm{~h}$, and changed levels of c-Myc, TERT, Bak ,DR5, c-FLIP $\mathrm{L}_{\mathrm{s}}, \mathrm{Mcl}-1$ and p21 were determined by western blotting. Actin was used as a loading control.

Amurensin $G$ potentiated TRAlL-induced cytotoxicity of MCF-7 cells through activation of caspase-8

Since above data showed that amurensin G directly induced up-regulation of DR5, we evaluated the cytotoxic effect of combined amurensin $G$ and TRAIL treatment in MCF-7 cells. The combination effect of amurensin G with TRAIL on MCF-7 cells was tested by MTT cell proliferation assay. As shown in Fig. 5, TRAIL-induced cytotoxicity of MCF-7 cells was significantly enhanced by amurensin G. This data showed that amurensin G potentiated TRAIL-induced cytotoxicity and sensitized MCF-7 cells to TRAIL.

It has been reported that the activation of TRAIL receptor leads to the cleavage and activation of pro-caspase- 8 , which leads to activation of caspase-3 via caspase 8-mediated cleavage of BID, amplifying caspase- 3 activation through caspase-9 [9]. Thus, we examined whether the increased susceptibility to TRAIL by amurensin $G$ was accompanied by the activations of caspase- 8 and caspase-7 since MCF-7 cells lack caspase- 3 but undergo mitochondrial-dependent apoptosis via caspase-7 activation. The cleavage and activation of both procaspase- 8 and procaspase-7 was significantly 

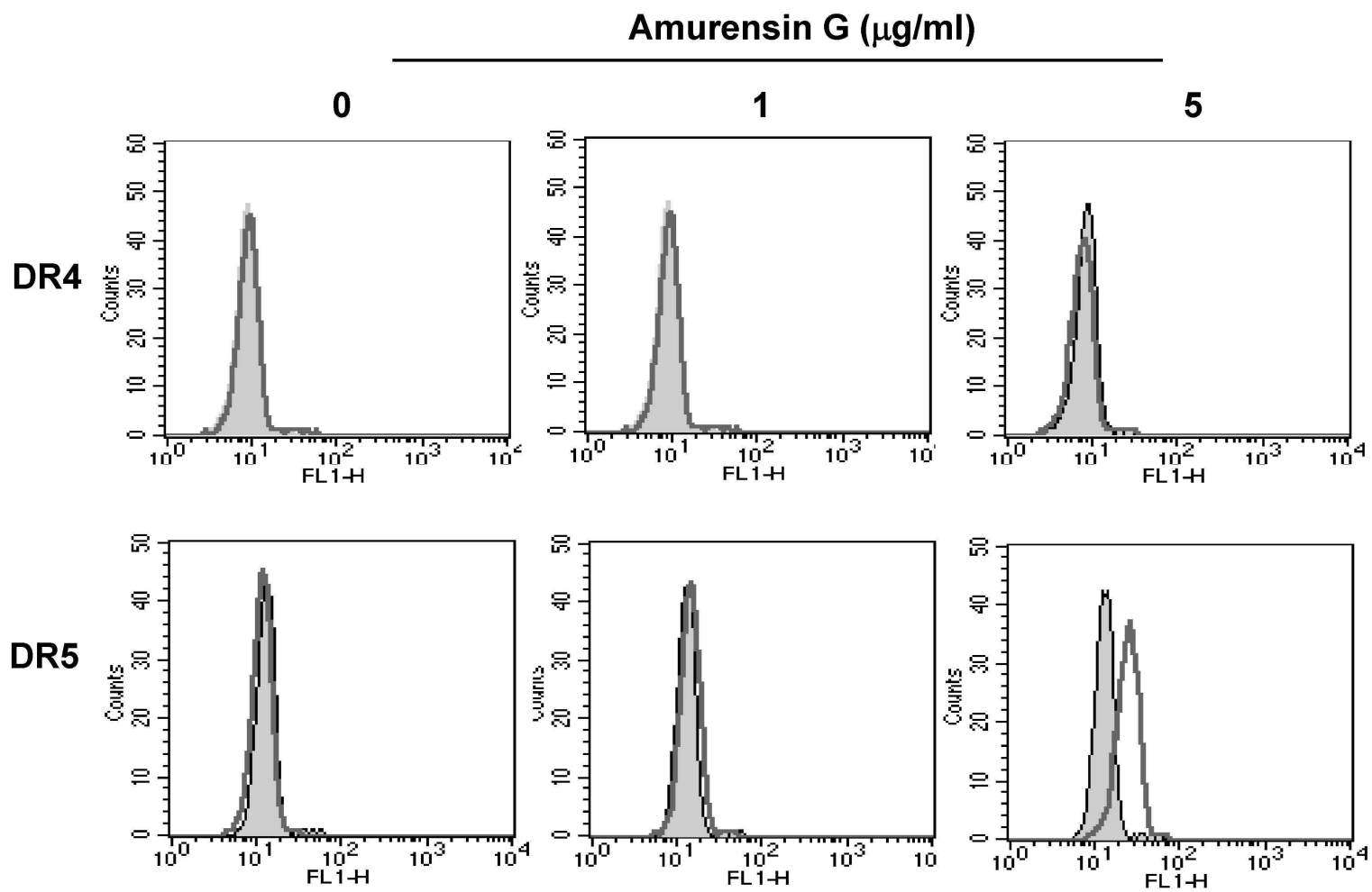

Fig. 4. Modulation by amurensin G of cell surface DR4/DR5 receptors expression. After treatment of MCF-7 cells with amurensin $\mathrm{G}(1-$ and $5 \mathrm{\mu g} / \mathrm{ml})$ for $8 \mathrm{~h}$, cells were labeled with control IgG, anti-DR4 or DR5 antibody (1:100) and subsequently stained with FITC-conjugated secondary antibodies (1:200). Cell surface expressions of DR4 and DR5 were quantified by flow cytometry. Shaded and unshaded peaks corresponded to control and specific stainings, respectively.

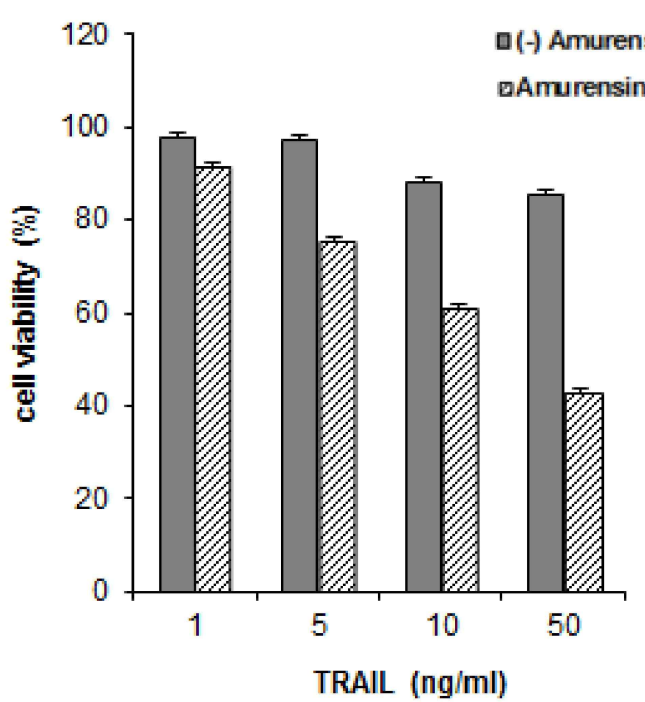

Fig. 5. Enhancement of TRAIL-induced cytotoxicity by amurensin G. MCF-7 cells were treated with various concentrations of TRAIL $(1 \sim 50 \mathrm{ng} / \mathrm{ml})$ in the presence or absence of amurensin G (5 $\mu \mathrm{g} / \mathrm{ml})$ for $96 \mathrm{~h}$. Cell survival was determined using MTT assay. Each value represents the mean $\pm \mathrm{SE}$ of triplicate experiments.

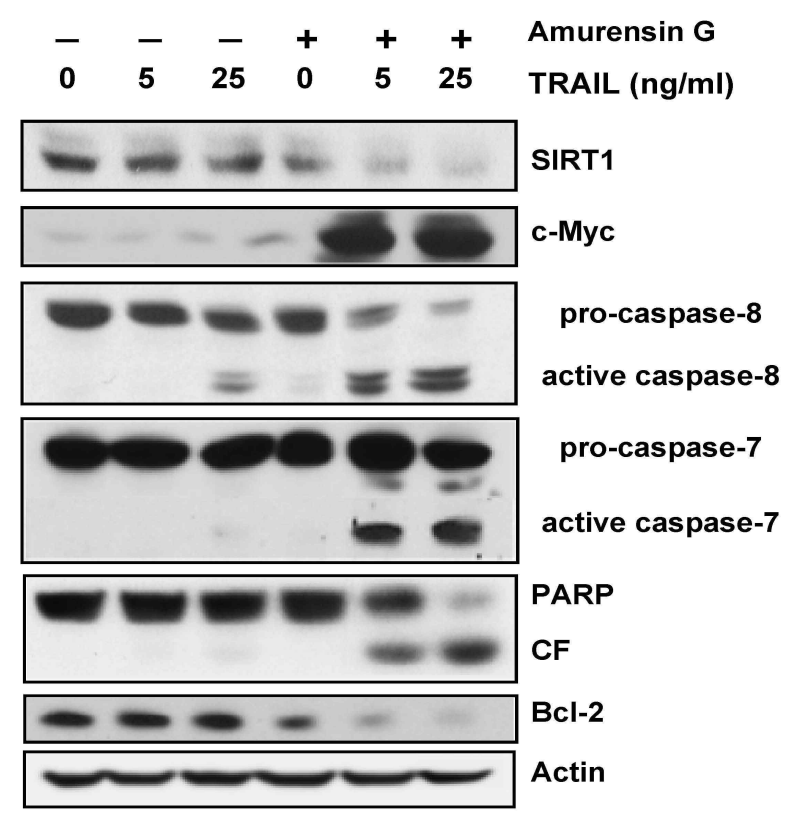

Fig. 6. Up-regulation of c-Myc and enhancement of TRAIL-induced caspase activation by amurensin G. MCF-7 cells were treated with TRAIL ( 5 or $25 \mathrm{ng} / \mathrm{ml}$ ) in the presence or absence of amurensin $\mathrm{G}(5 \mu \mathrm{g} / \mathrm{ml})$ for $24 \mathrm{~h}$ and the cleavage of pro-caspases and PARP, and Bcl-2 level were determined by western blotting. $\mathrm{CF}$, cleavage fragments. 


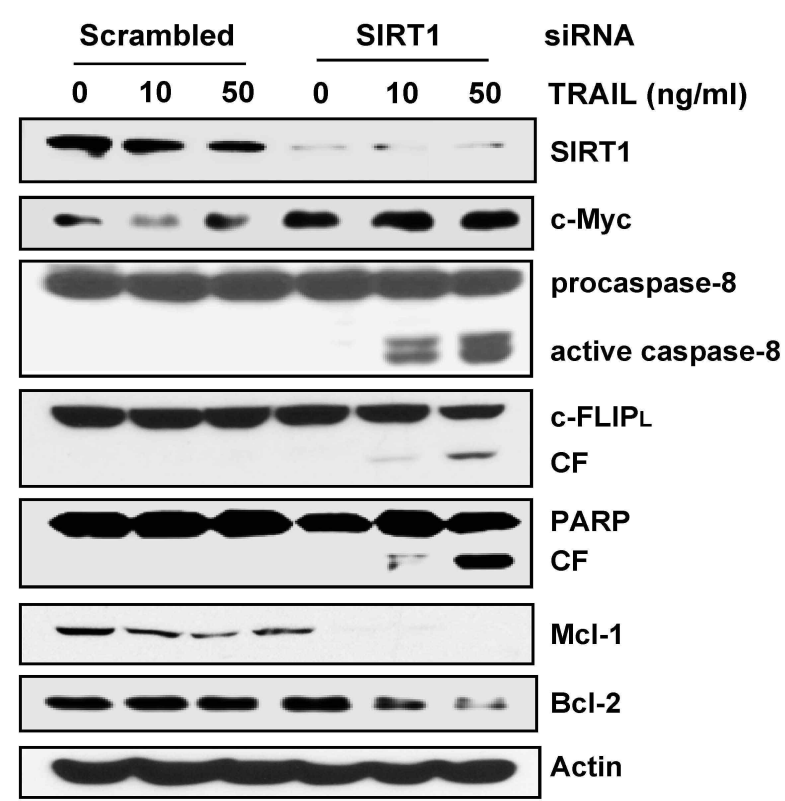

Fig. 7. Enhancement of TRAIL-induced activation of caspase-8 and inactivation of c-FLIP by inhibition of SIRT1. MCF-7 cells were transfected with SIRT1 siRNA or scrambled siRNA and after $48 \mathrm{~h}$ treated with TRAIL ( 5 or $25 \mathrm{ng} / \mathrm{ml}$ ) for $8 \mathrm{~h}$. Western blotting was performed to determine levels of SIRT1, Bax and Bcl-2, and cleavage of PARP, pro-caspase -8 .

higher in MCF-7 cells co-treated with TRAIL and amurensin $G$ than in cells treated with TRAIL alone via up-regulation of c-Myc and down-regulation of SIRT1. These results were followed by the increased cleavage of PARP, a hallmark of caspase-dependent apoptosis. We further examined whether SIRT1 inhibition could modulate antiapoptotic Bcl-2 proteins during TRAIL-induced apoptosis. In the MCF-7 cells co-treated with TRAIL and amurensin G, the level of Bcl-2 was remarkably decreased as compared with the cells treated with TRAIL alone. These results suggest that the inhibition of SIRT1 can sensitize TRAIL-resistant MCF-7 cells to TRAIL by caspase activation involved in TRAIL pathway.

Knockdown of SIRT1 enhanced TRAIL-induced
caspase-8-dependent apoptosis and down-regulation
of -FLIP and Mcl-1

To further confirm that inhibition of SIRT1 could affect TRAIL-mediated apoptotic pathways involved activation of the caspase-8 and down-regulation of c-FLIP, we examined whether knockdown of SIRT1 could modulate the activity of caspase-8 and the expression of c-FLIP. When MCF-7 cells were transfected with SIRT1 siRNA, SIRT1 expression was profoundly suppressed and subsequently expressions of
c-Myc, the cleavage of procaspase- 8 and c-FLIP ${ }_{\mathrm{L}}$ and subsequent activation of caspase- 8 were occurred, which was followed by the increased cleavage of PARP, down-regulation of Bcl-2 and Mcl-1. These findings suggest that knockdown of SIRT1 enhanced TRAIL-induced caspase-8-dependent apoptosis through down-regulation of c-FLIP and Mcl-1.

\section{Discussion}

In this study, we found that inhibition of SIRT1 in TRAIL-resistant enhanced susceptibility to TRAIL. The mechanism responsible for the potentiation effect of SIRT1 inhibition on TRAIL-induced apoptosis was found to involve mainly in the up-regulation of DR5 and the down-regulation of c-FLIP through modulation of c-Myc expression. We also revealed that amurensin G, a potent new SIRT1 inhibitor isolated from Vitis amurensis, would be used as a sensitizer of TRAIL in TRAIL-resistant cancer cells.

HDAC inhibitors appear to lower the apoptotic threshold by decreasing the expressions of anti-apoptotic genes, and thus, there is a strong rationale for combining HDAC inhibitors with direct activators of the apoptotic process [21]. Synergistic tumor cell death has been reported in a variety of human cancers using different HDAC inhibitors together with TRAIL, and understanding of the molecular mechanism that underlie the synergistic interaction of HDAC inhibitor and TRAIL can be used to design applied the design of cancer-selective novel therapeutics [7].

Inhibitors of HDAC were recently shown to increase cell death induced by TRAIL in weakly TRAIL-sensitive cancer cells [28]. It has been reported that trichostatin A (TSA) or suberoylanilide hydroxamic acid (SAHA), the class I and II HDAC inhibititor can sensitize TRAIL-resistant cancer cells to TRAIL-induced apoptosis $[19,29]$. But, the role of class III HDAC inhibition in enhancing death receptor-mediated apoptosis was not well documented.

In the present study, we showed that a class III HDAC amurensin G or knockdown of SIRT1 enhanced TRAIL-induced cytotoxicity in TRAIL-resistant MCF-7 cells. In addition, the cell surface expression of DR5, but not of DR4, was found to be increased in MCF-7 cells after treatment amurensin G. These results suggest that DR5 up-regulation might be an importnat role in SIRT1 inhibition-mediated potentiation of TRAIL-induced cell death. Indeed, it has been reported that suberoylanilide hydroxamic acid, m-carboxycinnamic acid bis-hydroxamide, MS-275 and TSA, the class I 
and II HDAC inhibitors, synergized with TRAIL by inducing DR4 and/or DR5 through NF-kB activation in breast cancer cells in vitro [28]. The expression of DR5 can be regulated transcriptionally by various transcription factors $[15,27,32]$.

We revealed that c-Myc was increased by knock-down of SIRT1 or treatment with amurensin G, indicating that up-regulation of DR5 by inhibition of SIRT1 might be associated with the up-regulation of c-Myc. Since SIRT1 could interact with and deacetylates c-Myc and reduced c-Myc stability [34], our data indicated the possibility that inhibition of SIRT1 by knock-down of SIRT1 or treatment with amurensin G would increase c-Myc stability, and consequently potentiate TRAIL-induced cell death.

c-Myc also repressed expression of c-FLIP and Mcl-1 transcription and thus rendered resistant human cancer cells sensitive to TRAIL-induced death $[22,23]$. Since our data showed that the inhibition of SIRT1 with amurensin G or knockdown of SIRT1 down-regulated the expression of c-FLIP and Mcl-1, which might be associated with up-regulation of c-Myc.

The up-regulation of DR5 and c-Myc induced by knock-down of SIRT1 or treatment with amurensin G was followed by augmentation of the activation of caspase- 8 and Bax, PARP cleavage, during the TRAIL-induced apoptosis in MCF-7 cells. c-Myc can prime mitochondria through a mechanism involving the activation of Bak, enabling weak TRAIL-induced caspase-8 signals to activate Bax [16] and siRNA-mediated depletion of c-Myc in metastatic cancer cells suppressed the TRAIL-induced up-regulation of DR5 and activation of caspases [11].

Taken together, our study showed that the suppression of SIRT1 significantly increased TRAIL-induced cytotoxicity via the DR5 surface expression and the down-regulations of c-FLIP and Mcl-1, and up-regulation of c-Myc by SIRT1 inhibition was involved in sensitization of resistant MCF-7 cell to TRAIL.

\section{Acknowledgement}

This work was supported by a 2-Year Research Grant of Pusan National University.

\section{References}

1. Aron, J. L., Parthun, M. R., Marcucci, G., Kitada, S., Mone, A. P., Davis, M. E., Shen, T., Murphy, T., Wickham, J.,
Kanakry, C., Lucas, D. M., Reed, J. C., Grever, M. R. and Byrd, J. C. 2003. Depsipeptide (FR901228) induces histone acetylation and inhibition of histone deacetylase in chronic lymphocytic leukemia cells concurrent with activation of caspase 8-mediated apoptosis and down-regulation of c-FLIP protein. Blood 102, 652-658.

2. Ashkenazi, A., Pai, R. C., Fong, S., Leung, S., Lawrence, D. A., Marsters, S. A., Blackie, C., Chang, L., McMurtrey, A. E., Hebert, A., DeForge, L., Koumenis, I. L., Lewis, D., Harris, L., Bussiere, J., Koeppen, H., Shahrokh, Z. and Schwall, R. H. 1999. Safety and antitumor activity of recombinant soluble Apo2 ligand. J. Clin. Invest. 104, 155-162.

3. Bevis, K. S., Buchsbaum, D. J. and Straughn, J. M., Jr. 2010. Overcoming TRAIL resistance in ovarian carcinoma. Gynecol. Oncol. 119, 157-163.

4. Bhalla, K. N. 2005. Epigenetic and chromatin modifiers as targeted therapy of hematologic malignancies. J. Clin. Oncol. 23, 3971-3993.

5. Bolden, J. E., Peart, M. J. and Johnstone, R. W. 2006. Anticancer activities of histone deacetylase inhibitors. Nat. Rev. Drug Discov. 5, 769-784.

6. Camphausen, K., Scott, T., Sproull, M. and Tofilon, P. J. 2004. Enhancement of xenograft tumor radiosensitivity by the histone deacetylase inhibitor MS-275 and correlation with histone hyperacetylation. Clin. Cancer Res. 10, 6066-6071.

7. Carew, J. S., Giles, F. J. and Nawrocki, S. T. 2008. Histone deacetylase inhibitors: mechanisms of cell death and promise in combination cancer therapy. Cancer Lett. 269, 7-17.

8. Fulda, S. 2008. Modulation of TRAIL-induced apoptosis by HDAC inhibitors. Curr. Cancer Drug Targets 8, 132-140.

9. Hall, M. A. and Cleveland, J. L. 2007. Clearing the TRAIL for Cancer Therapy. Cancer Cell 12, 4-6.

10. Hernandez, A., Thomas, R., Smith, F., Sandberg, J., Kim, S., Chung, D. H. and Evers, B. M. 2001. Butyrate sensitizes human colon cancer cells to TRAIL-mediated apoptosis. Surgery 130, 265-272.

11. Kim, H. B., Kim, M. J., Kim, D. Y., Lee, J. W., Bae, J. H., Kim, D. W., Kang, C. D. and Kim, S. H. 2011. High susceptibility of metastatic cells derived from human prostate and colon cancer cells to TRAIL and sensitization of TRAIL-insensitive primary cells to TRAIL by 4,5-dimethoxy-2-nitrobenzaldehyde. Mol. Cancer 10, 46.

12. Kim, M. S., Blake, M., Baek, J. H., Kohlhagen, G., Pommier, Y. and Carrier, F. 2003. Inhibition of histone deacetylase increases cytotoxicity to anticancer drugs targeting DNA. Cancer Res. 63, 7291-7300.

13. Kruyt, F. A. 2008. TRAIL and cancer therapy. Cancer Lett. 263, 14-25.

14. Liu, N., Zhang, J., Zhang, J., Liu, S., Liu, Y. and Zheng, D. 2008. Erbin-regulated sensitivity of MCF-7 breast cancer cells to TRAIL via ErbB2/AKT/NF-kappaB pathway. J. Biochem 143, 793-801.

15. Mahajan, S., Dammai, V., Hsu, T. and Kraft, A. S. 2008. Hypoxia-inducible factor-2alpha regulates the expression of TRAIL receptor DR5 in renal cancer cells. Carcinogenesis 29, 1734-1741. 
16. Nieminen, A. I., Partanen, J. I., Hau, A. and Klefstrom, J. 2007. c-Myc primed mitochondria determine cellular sensitivity to TRAIL-induced apoptosis. EMBO J. 26, 1055-1067.

17. Oh, W. K., Cho, K. B., Hien, T. T., Kim, T. H., Kim, H. S., Dao, T. T., Han, H. K., Kwon, S. M., Ahn, S. G., Yoon, J. H., Kim, T. H., Kim, Y. G. and Kang, K. W. 2010. Amurensin G, a potent natural SIRT1 inhibitor, rescues doxorubicin responsiveness via down-regulation of multidrug resistance 1. Mol. Pharmacol. 78, 855-864.

18. Olmos, Y., Brosens, J. J. and Lam, E. W. 2011. Interplay between SIRT proteins and tumour suppressor transcription factors in chemotherapeutic resistance of cancer. Drug Resist. Updat. 14, 35-44.

19. Park, S. J., Kim, M. J., Kim, H. B., Sohn, H. Y., Bae, J. H., Kang, C. D. and Kim, S. H. 2009. Trichostatin A sensitizes human ovarian cancer cells to TRAIL-induced apoptosis by down-regulation of c-FLIPL via inhibition of EGFR pathway. Biochem Pharmacol. 77, 1328-1336.

20. Pathil, A., Armeanu, S., Venturelli, S., Mascagni, P., Weiss, T. S., Gregor, M., Lauer, U. M. and Bitzer, M. 2006. HDAC inhibitor treatment of hepatoma cells induces both TRAIL-independent apoptosis and restoration of sensitivity to TRAIL. Hepatology 43, 425-434.

21. Perego, P., Zuco, V., Gatti, L. and Zunino, F. 2012. Sensitization of tumor cells by targeting histone deacetylases. Biochem Pharmacol. 83, 987-994.

22. Ricci, M. S., Jin, Z., Dews, M., Yu, D., Thomas-Tikhonenko, A., Dicker, D. T. and El-Deiry, W. S. 2004. Direct repression of FLIP expression by c-myc is a major determinant of TRAIL sensitivity. Mol. Cell Biol. 24, 8541-8555.

23. Ricci, M. S., Kim, S. H., Ogi, K., Plastaras, J. P., Ling, J., Wang, W., Jin, Z., Liu, Y. Y., Dicker, D. T., Chiao, P. J., Flaherty, K. T., Smith, C. D. and El-Deiry, W. S. 2007. Reduction of TRAIL-induced Mcl-1 and cIAP2 by c-Myc or sorafenib sensitizes resistant human cancer cells to TRAIL-induced death. Cancer Cell 12, 66-80.

24. Schuchmann, M., Schulze-Bergkamen, H., Fleischer, B., Schattenberg, J. M., Siebler, J., Weinmann, A., Teufel, A., Worns, M., Fischer, T., Strand, S., Lohse, A. W. and Galle, P. R. 2006. Histone deacetylase inhibition by valproic acid down-regulates c-FLIP/CASH and sensitizes hepatoma cells towards CD95- and TRAIL receptor-mediated apoptosis and chemotherapy. Oncol. Rep. 15, 227-230.

25. Shankar, S. and Srivastava, R. K. 2004. Enhancement of therapeutic potential of TRAIL by cancer chemotherapy and irradiation: mechanisms and clinical implications. Drug Resist. Updat. 7, 139-156.

26. Sheridan, J. P., Marsters, S. A., Pitti, R. M., Gurney, A., Skubatch, M., Baldwin, D., Ramakrishnan, L., Gray, C. L., Baker, K., Wood, W. I., Goddard, A. D., Godowski, P. and Ashkenazi, A. 1997. Control of TRAIL-induced apoptosis by a family of signaling and decoy receptors. Science 277, 818-821.

27. Shetty, S., Graham, B. A., Brown, J. G., Hu, X., Vegh-Yarema, N., Harding, G., Paul, J. T. and Gibson, S. B. 2005. Transcription factor NF-kappaB differentially regulates death receptor 5 expression involving histone deacetylase 1 . Mol. Cell Biol. 25, 5404-5416.

28. Singh, T. R., Shankar, S. and Srivastava, R. K. 2005. HDAC inhibitors enhance the apoptosis-inducing potential of TRAIL in breast carcinoma. Oncogene 24, 4609-4623.

29. Sonnemann, J., Gange, J., Kumar, K. S., Muller, C., Bader, P. and Beck, J. F. 2005. Histone deacetylase inhibitors interact synergistically with tumor necrosis factor-related apoptosis-inducing ligand (TRAIL) to induce apoptosis in carcinoma cell lines. Invest. New Drugs 23, 99-109.

30. Suliman, A., Lam, A., Datta, R and Srivastava, R. K. 2001. Intracellular mechanisms of TRAIL: apoptosis through mitochondrial-dependent and -independent pathways. Oncogene 20, 2122-2133.

31. Walczak, H., Miller, R. E., Ariail, K., Gliniak, B., Griffith, T. S., Kubin, M., Chin, W., Jones, J., Woodward, A., Le, T., Smith, C., Smolak, P., Goodwin, R. G., Rauch, C. T., Schuh, J. C. and Lynch, D. H. 1999. Tumoricidal activity of tumor necrosis factor-related apoptosis-inducing ligand in vivo. Nat. Med 5, 157-163.

32. Wang, Y., Engels, I. H., Knee, D. A., Nasoff, M., Deveraux, Q. L. and Quon, K. C. 2004. Synthetic lethal targeting of MYC by activation of the DR5 death receptor pathway. Cancer Cell 5, 501-512.

33. Watanabe, K., Okamoto, K. and Yonehara, S. 2005. Sensitization of osteosarcoma cells to death receptor-mediated apoptosis by HDAC inhibitors through downregulation of cellular FLIP. Cell Death Differ. 12, 10-18.

34. Yuan, J., Minter-Dykhouse, K. and Lou, Z. 2009. A c-Myc-SIRT1 feedback loop regulates cell growth and transformation. J. Cell Biol. 185, 203-211.

35. Zhang, L. and Fang, B. 2005. Mechanisms of resistance to TRAIL-induced apoptosis in cancer. Cancer Gene Ther. 12, 228-237. 
초록 : SIRT1 억제에 의한 DR5 발현증강과 C-FLIP 발현저해 작용으로 사람유방암세포 MCF-7의 TRAIL 감수성 증강

이수훈 ${ }^{1} \cdot$ 김학봉 $^{1} \cdot$ 김미주 $^{1} \cdot$ 이재원 ${ }^{1} \cdot$ 배재호 $^{1} \cdot$ 김동완 ${ }^{2} \cdot$ 강치덕 $^{1} \cdot$ 김선희 $^{1}{ }^{*}$ (부산대학교 의학전문대학원 생화학교실, ${ }^{2}$ 창원대학교 자연과학대 미생물학과)

Tumor necrosis factor-related apoptosis-inducing ligand (TRAIL)은 암세포 선택적으로 작용하므로서 유용한 항암제로 주목 받고 있다. 그러나, TRAIL 에 내성을 나타내는 암세포도 많이 존재한다. 그러므로 TRAIL 내성을 극복할 수 있는 방법을 고안하는 연구는 암 치료 요법에 매우 중요하다. 본 연구에서는 SIRT1 siRNA 또는 SIRT1 inhibitor인 amurensin $\mathrm{G}$ 를 사람 유방암세포에 처리하면 DR5및 c-Myc의 발현 증강과 c-FLIP $\mathrm{L}_{\mathrm{S} / \mathrm{s}}$ 및 Mcl-1 발현 억제를 유도하므로서, TRAIL 에 내성을 나타내는 사람유방암세포 MCF-7 세포의 TRAIL 감수성을 증강시킴을 알 수 있었다. 또한, SIRT1 억제에 의한 caspase 활성화, PARP cleavage 및 Bcl-2 발현감소를 나타내었다. 이러한 연구결과는 SIRT1 저해에 의한 DR5 유도와 함께 c-FLIP 발현 억제가 TRAIL 내성 암세포의 TRAIL 반응성 증강 에 유용한 기전으로 사용 될 수 있음을 시사하였다. 